\title{
A HISTÓRIA: UM TERRITÓRIO SEM FRONTEIRAS
}

\section{HISTORY: A TERRITORY WITHOUT FRONTIERS}

\section{Jean-Pierre Goubert}

GOUBERT, J. R. A história: um território sem fronteiras. Rev. Bras. Cresc. Desenv. Hum., São Paulo, 10 (2), 2000.

Resumo: Fruto de sua trajetória como historiador, o autor expõe, de forma sintética, a súmula de seu pensamento a respeito de sua disciplina e de possíveis interfaces entre ela e áreas afins, para concluir que, "fazer história nao é somente existir, é 'ser': ser conforme a vocação de toda pessoa humana: a do Homo sapiens sapiens.”

Palavras-chave: história; interfaces.

Há cerca de 20 anos atrás, Chris Marker escreveu: “A História é sempre uma passagem de uma fronteira”. A recíproca, em minha opinião, é igualmente verdadeira: "a passagem de uma fronteira, é sempre história”. Seja uma história de vida, uma história vivida, uma história contada: sem história, não há História, não há Vida igualmente, apenas fronteiras.

Conforme a etimologia grega do termo, a História é uma pesquisa, uma investigação tanto individual quanto coletiva, em suma, uma tentativa de desvelamento da verdade. Porque o ser humano é linguagem, porque o corpo, este espaço / tempo configurado, habitado, incorporado é o símbolo dos símbolos, ele não pode prescindir da História, de sua história, da história de seu "parto", tanto corporal quanto espiritual, de sua infância, da história das instituições, de seu país, de sua "instituição" enquanto pessoa.

A história, por sua vez, recomeça indefinidamente, mudando de forma e de aparência. A busca é sempre - todos os dias, todos os períodos históricos reunidos -, a da identidade, com seus fundamentos, suas dicotomias, seus estereótipos, seus avatares, suas ambições, suas mágoas, seus falseamentos, suas conquistas, suas derrotas, em suma: sua caminhada.

Diferenternente das experiências na Física, a História não se repete nunca de modo idêntico. Ela anuncia, ela balbucia, ela segue, ela acompanha, ela precede, ela antecipa, ela se exerce no governo de si, de nosso percurso individual e social, econômico e sagrado.

Nesta perspectiva, ser historiador não é somente uma profissão de tipo universitário nem, certamente, uma especialização. E uma profissão para a qual estamos todos convidados, na medida em que temos consciência de nós mesmos e do mundo em que vivemos, microcosmo bio-celular e macrocosmo universal aí incluídos.

Nesta perspectiva ainda, o sentido ético pelos valores que a inspiram, implica em uma alforria, uma liberação, uma permeabilidade osmótica entre as línguas, os jargões profissionais, as gírias diversas, a fim de melhor desvendar os segredos da linguagem.

1 Professor da École des Hautes Études em Sciences Sociales, Paris, França, especializado em História Social e História da Saude. End.: 54, Boulevard Raspail. 75006, Paris, França. Traducão: Elaine Pedreira Rabinovich. 
Nesta perspectiva, enfim, traçar "sua” história, ter uma história, dizer sua história, é franquear uma passagem, passar fronteiras, atravessálas, enriquecer-se após tê-las descoberto, reconhecido, balizado, trate-se de fronteiras de tipo geográfico, civilizatório ou cronológico.

De maneira erudita, a História retraça um passado. De modo filosófico e heurístico, ela é filha do presente, de um presente imanente, ao mesmo tempo imóvel e mutante, identitário e versátil, perturbador e confortante.

Devolvendo seu espaço de verdade à linguagem, o historiador põe em acordo os mais diferentes idiomas. Quero oferecer como prova o exemplo e o modelo, l'exemplum, da palavra "célula”. Uma cella é o espaço sagrado onde se en- contra a Divindade nos templos pagãos da Roma antiga. Ela é vazia, indissociável, porque invisível. A célula, diminutivo de cella, é de tipo molecular e marca a biologia. Humana, ela permanece indissociável; humana, ela é programada para morrer, por apoptose (língua médica). Célula do prisioneiro, ela é fechada por uma porta, por barras. E é pelo espírito que "o prisioneiro" se evade, repete, escreve, fala, age. Existem, assim, células do espírito, prisões do espírito, no instante, durante uma geração, numa família, e também na "longa duração". É o se libertar que permite a História. Nestas condições, fazer história não é somente existir, é "ser”: ser conforme a vocação de toda pessoa humana: a do Homo sapiens sapiens.

Abstract: A product of bis work as a historian, the author exposes, in a synthetic way, his thinking as to bis discipline and possible interfaces between it and correlated arcas. He concludes that "to make history is not only to exist, it is 'to be' in accord with the vocation of every human being: that of the Homo sapiens sapiens.

Key words: history; interfaces. 